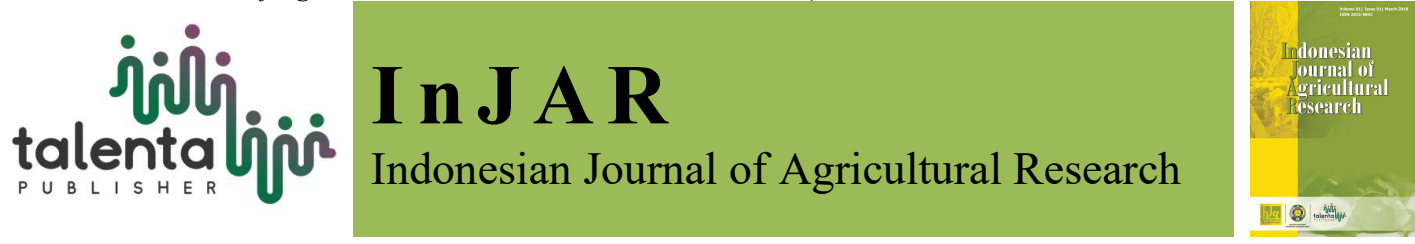

\title{
Organoleptic Test of Salted Eggs with Addition of Herbal Plants
}

\author{
Nur'aini", Nining Suningsih, and Muhammad Hakim \\ Poultry Production Technology Study Program, Akademi Komunitas Negeri Rejang Lebong, Curup, \\ Indonesia
}

\begin{abstract}
The addition of salt and herbal plants such as bay leaf (Eugenia polyantha) and lemongrass (Cymbopogon citratus DC) extacts can extender the shelf life and increase the flavor of the salted eggs. The purpose of this study was to determine the quality of eggs produced from using the herbal plants in terms of the organoleptic testing. This research used eggs from laying hens with salted egg making media consisting of rubbing ash plus salt, supplemented with bay leaf (Eugenia polyantha), lemongrass (Cymbopogon citratus DC), with storage period of 10 days. Organoleptic test results showed that the addition of bay leaves and lemongrass to the production of salted eggs, did not significantly improve the quality of salted eggs produced. The lack of storage time in the egg marinating process led to the incomplete, in salt water absorption into the egg. It is concluded that the addition of bay leaves and lemongrass to the media of making salted chicken eggs did not have a significantly different effect on the organoleptic quality of the salted eggs.
\end{abstract}

Keywords: herbal plants, organoleptic test, salted egg

Received 30 June 2020 | Revised 6 July 2020 | Accepted 7 November 2020

\section{Introduction}

Broiler chicken eggs are one of the animal food sources that have lower cholesterol levels compared to duck eggs, which are around $423.00 \mathrm{mg}$ [1]. In addition, chicken eggs also have relatively low prices and are easily obtained in the market, where the ease of access is caused by the rapid development of the poultry industry which tends to spread closer to consumers. However, purebred eggs also have some disadvantages including: the tin eggshells make them more prone to cracking as well as, the presence of very high temperature and humidity can cause physical, chemical and microbiological damages to the eggs.

Therefore, it is essential to add salt for in egg processing techniques, because the addition of salt and herbal plants such as bay leaf (Eugenia polyantha) and lemongrass (Cymbopogon citratus DC) in the process of preserving eggs functions as a preservative that can prevent spoilage of eggs because the presence of chemical content in the form of essential oils, tannins, flavonoids, and

\footnotetext{
*Corresponding author at: Poultry Production Technology Study Program, Akademi Komunitas Negeri Rejang Lebong, Jl. Basuki Rahmat Dwi Tunggal, Curup, Kabupaten Rejang Lebong, Provinsi Bengkulu, Indonesia

E-mail address: ainisiku@gmail.com
} 
eugenol, so it has the ability to inhibit the growth of bacteria that cause egg damage. In addition, the essential oil content that has a distinctive of scent on bay leaves and lemongrass can also reduce the fishy odor of eggs, which can improve flavor and better taste in salted eggs [2]. According to [3], bay leaves contain essential oils, tannins, flavonoids, and eugenol. Research [2] reported that the addition $25 \%$ of lemongrass leaf extract on salted duck eggs produced cause the scent produced not too fishy flavor. Meanwhile, at high concentrations $(75 \%)$ of lemongrass produced soft texture of salted eggs with scent dominant on the eggs. The purpose of this study was to determine the quality of salted eggs through organoleptic testing with the addition of bay leaves (Eugenia polyantha) and lemongrass (Cymbopogon citratus DC).

\section{Materials and Methods}

The ingredients used in this research were 60 eggs, rubbing ash, salt, bay leaves (Eugenia polyantha) and lemongrass (Cymbopogon citratus DC). This research uses a Completely Randomized Design consisting of 3 treatments and 5 replications. The treatments given in the research are: P0: Rub ash + salt (control); P1: Rub ash + salt + bay leaf (4: $4: 1)$; P2: Rub ash + salt + lemongrass $(4: 4: 1)$. Each dough is made in the form of a paste, then the eggs are doughed in with approximately the thickness of the dough $\pm 1 \mathrm{~cm}$ and stored for 10 days. Then harvest and do the boiling with \pm 30 minutes. Furthermore, the panelist preferred test, where panelists came from unapproved panelists with a total of 15 people. Measurement of egg quality through organoleptic tests by means of a sample inserted into a plastic container and presented to panelists includes egg yolk and albumen, texture, the scent and taste using 6 hedonic scales with perceptions of preference on the hedonic scale as follows: (1) Really dislike; (2) Dislike; (3) Rahter Dislike; (4) Like; (5) Really Like; (6) Really Like it a lot. Statistical analysis was undertaken using ANOVA [4], in which the significantly different results would be further followed by the Duncan's Multiple Range Test (DMRT).

\section{Results and Discussion}

Explains theoretical and empirical findings, including the comparison with previous studies and shows the contribution to the field of science. The size is no more than $50 \%$ of the total page. Results can be presented in figures and/or tables.

\subsection{The color of salted egg yolk}

The results of organoleptic tests based on color of salted egg yolk with the addition of herbal plants in the form of bay leaves (Eugenia polyantha) and lemongrass (Cymbopogon citratus) can be seen in Table 1. The addition of bay leaves (Eugenia polyantha) and lemongrass (Cymbopogon citratus) to salted egg media produced an egg yolk with yellow characteristics (scale 5,00), whereas in the control treatment the value scale was higher 
than the treatments P1 and P2, even though it was on the same characteristic namely yellow. This is because the egg has an outer shell that is coated by a protective form of cuticlea and membrane on the inside of the egg, causing salt solution and herbal plants extracts added to the media the rub ash can not enter and absorb perfectly into the egg.

Table 1. Addition of Herbal Plants to Salted Eggs Against the Egg Yolk Color

\begin{tabular}{ccc}
\hline Treatment & Egg Yolk Color & Characteristics \\
\hline P0 & $5,20 \pm 0,45$ & Yellow \\
P1 & $5,00 \pm 0,00$ & Yellow \\
P2 & $5,00 \pm 0,00$ & Yellow \\
\hline
\end{tabular}

According to [5] the outer shell (mineral) surrounds the contents of the egg, where the outer eggshell is wrapped in a protective wrapper called a cuticle or bloom which can help maintaining egg freshness and prevent microbial contamination. The use of bay leaves (Eugenia polyantha) and lemongrass (Cymbopogon citratus) in the manufacture of salted eggs can also slow the rate of diffusion of salt solution into the egg. The presence of Terpene compounds in bay leaves and lemongrass causes less salt solution enters the egg and then less water comes out from the egg. According to [6] the concentration of salt causes egg water content to decrease so that there is a change in the color of the yolk. Based on research [2] 75\% addition of lemongrass extract in the manufacture of salted eggs produced the highest salted egg water content, which was $49.72 \%$.

On the other hand, the lack of storage time in the egg marinating process, where the method of marinating eggs with a storage period of 10 days results in process of absorption of salt water into the egg which can reduce the water content in the egg, thereby affecting the color of the yolk. According to [7], soaking the eggs for 7-10 days in a salt solution produces salted eggs that taste salty enough to be enjoyed. The results of the statistical analysis showed that there was not significant difference between each treatment of the yolk color of salted eggs with a storage period of 10 days. This shows that the addition of herbal plants in the form of bay leaves (Eugenia polyantha) and lemongrass (Cymbopogon citratus) to the media for making salted broiler eggs have not been able to significantly change the color of the yolk to the color of orange according to the yellow color change in salted eggs.

\subsection{The albumen color of salted egg}

Organoleptic test on albumen as the results of herbal plants in the form of bay leaves (Eugenia polyantha) and lemongrass (Cymbopogon citratus) addition can be seen in Table 2 . Characteristics of albumen produced from either egg covered by control or treated media was transparent. This is because the bay leaves (Eugenia polyantha) and lemongrass (Cymbopogon citratus) have pigment content in the form of chlorophyll (leaf green 
substance) id unstable, so that when refinement is carried out there willl be a process of degradation (discoloration) on bay leaf extract and lemongrass.

Table 2. Addition of Herbal Plants to Salted Eggs Against Egg Albumen

\begin{tabular}{ccc}
\hline Treatment & Albumen Color & Characteristics \\
\hline P0 & $6,00 \pm 0,00$ & White \\
P1 & $6,00 \pm 0,00$ & White \\
P2 & $6,00 \pm 0,45$ & White \\
\hline
\end{tabular}

In addition, bay leaves and lemongrass contain terpene and terpenoid compounds which are colorless and distinctive scent which is known as essesntial oils, where the essential oils are easily oxidized when exposed to light and air. According to [8] Lemongrass contains a citronellal substance which is a colorless liquid that produces esters and has a nice smell. Previous research [2] reported that the addition of $25 \%, 50 \%, 50 \%$ and $75 \%$ of citronella extract, with 14 days of marinating at room temperature did not affect the color of salted eggs. In this result, the addition herbal plants in the form of bay leaves (Eugenia polyantha) and lemongrass (Cymbopogon citratus) on the media in producing broiler salted egg gave no statistically significant effect on albumen color.

\subsection{Texture of salted eggs}

Organoleptic tests on the texture of salted eggs due to the addition of herbal plants in the form of bay leaves (Eugenia polyantha) and lemongrass (Cymbopogon citratus) presented in Table 3. It can be seen from the Table that the texture of normal egg was slightly sandy, while treated eggs had slightly rubbery sandy characteristics. The elasticity of salted eggs in each treatment is due to the salting process using salt. During the process, salt $(\mathrm{NaCl})$ has an ability to bind water that has a greater affinity than protein, causing the distance between protein molecules get closer resulted in the interactions between molecules protein is getting stronger. Later, the strong bond will cause the protein to clot, so that the texture of the protein will be springier.

Table 3. Addition of Herbs in Salted Eggs to the Texture of Salted Eggs

\begin{tabular}{ccl}
\hline Treatment & Egg Texture $^{(\mathrm{tn})}$ & \multicolumn{1}{c}{ Characteristics } \\
\hline P0 & $3,40 \pm 0,89$ & Rather Chewy and Gritty \\
P1 & $4,00 \pm 0,00$ & Rather Chewy and Gritty \\
P2 & $4,20 \pm 0,45$ & Rather Chewy and Gritty \\
\hline
\end{tabular}

According to [9] the level of chewy tends to increase as an impact of water content, in which less water content produces a chewy texture. Other study [10] found that very chewy texture of salted egg was obtained in the treatment using ash concentration of 60 grams: salt 80 gram. In addition, the osmotic dehydration process from salting can also produce an egg yolk/sandy texture. 
Furthermore, the addition of bay leaves and lemongrass can also produce a sour texture of marinade in egg yolks, because bay leaves (Eugenia polyantha) and lemongrass (Cymbopogon citratus) tannins. The amount of tannin are more abundant in lemongrass leaves (Cymbopogon citratus), where the tannin can reacts with egg protein (albumin) and hydrogen dioxide, to form a precipitation. The reaction leads to an increase in the value of egg texture, in which removing water from the material into the solution cause the salted eggs are drier and harder [11]. [2] The application of $75 \%$ lemongrass to salted eggs produced a harder texture of salted eggs. This study showed that the addition of herbal plants in the form of bay leaves (Eugenia polyantha) and lemongrass (Cymbopogon citarus) on the media for making salted chicken eggs provided no significant difference on the texture changes.

\subsection{The smell of salted eggs}

The smell of salted eggs with the addition of herbal plants in the form of bay leaves (Eugenia polyantha) and lemongrass (Cymbopogon citratus) can be seen in Table 4. According to [12] salted eggs can be made with salting dough consisting of a mixture of rubbing ash and salt in a ratio of $1: 1$. Even though the ratio between salt and rubbing ash is suitable, all control and treated eggs had similar smell. The lack of storage and ripened time cause salt entering the egg is not optimal.

Table 4. Addition of Herbal Plants to Salted Eggs Against the Smell of Salted Eggs

\begin{tabular}{ccl}
\hline Treatment & The Smell of Salted Egg & Characteristics \\
\hline P0 & $3,40 \pm 1,67$ & Rather Fishy Odor \\
P1 & $3,20 \pm 0,45$ & Rather Fishy Odor \\
P2 & $4,00 \pm 1,41$ & A little Not Fishy Odor \\
\hline
\end{tabular}

Previous research noted that fishy smell found in eggs decreased with ripening for 20 days, the longer the eggs are smothered in salt and brick dough, the lesser the fishy smell in the salted eggs [13]. In addition, the presence of phenol compounds in the form of tannins in bay leaves (Eugenia polyantha) and lemongrass (Cymbopogon citarus) can also cover the pores in the eggshell, thereby inhibiting the entry of salt in the media into the egg [12]. Moreover, soaking salted eggs with steeping extracts and bay leaf powder for 12 hours or 24 hours produced a soft texture, dull white color, brownish yellow and dark yellow of yolks, fishy smell and taste like salted eggs in general [14].

But on the other side, the slight fishy smell of eggs in the addition of lemongrass (Cymbopogon citratus) is caused by the presence of essential oil (consisting of Citral and Eugenol) which functions as a binding odor and has a smell good, so as to reduce the fishy odor and give a distinctive smell in salted eggs. According to [15] lemongrass is one of the plants that produce essential oils which acts as a binding agent for odor. Other researcher [8] added that lemongrass contains citronellal substance which is a liquid that does not contain esters and has a smell good. 
However, this study found that the addition of herbal plants in the form of bay leaves (Eugenia polyantha) and lemongrass (Cymbopogon citratus) on the media of broiler salted egg production did not statistically change the smell of the salted eggs.

\subsection{Taste of salted eggs}

The taste of salted eggs with the addition of herbal plants in the form of bay leaves (Eugenia polyantha) and lemongrass (Cymbopogon citarus) based on organoleptic test can be seen in Figure 1. The higher level of preference for salted eggs with the addition of lemongrass (Cymbopogon citarus) compared to the control was related to the aroma of the product that slightly less fishy. Lemongrass leaves (Cymbopogon citratus) contains citronellal substances and essential oils (sitral and eugenol) with distinctive scent and spicy taste that can bind odors and absorb / in to the eggs during the ripening process, Therefore, the substance can, reduce the fishy odor and give a distinctive smell of salted eggs. In contrast, the taste of salted eggs with mixing media of bay leaves (Eugenia polyantha) was less preferred because the bay leaves contained less essential oil, the taste was bitter and the smell was not too strong. According to [2] the addition of $25 \%$ lemongrass extract to salted eggs did not have a significant effect. This study found that the addition of herbal plants in the form of bay leaves (Eugenia polyantha) and lemongrass (Cymbopogon citratus) on the media of broiler salted egg production did not statistically change the taste of the salted eggs.

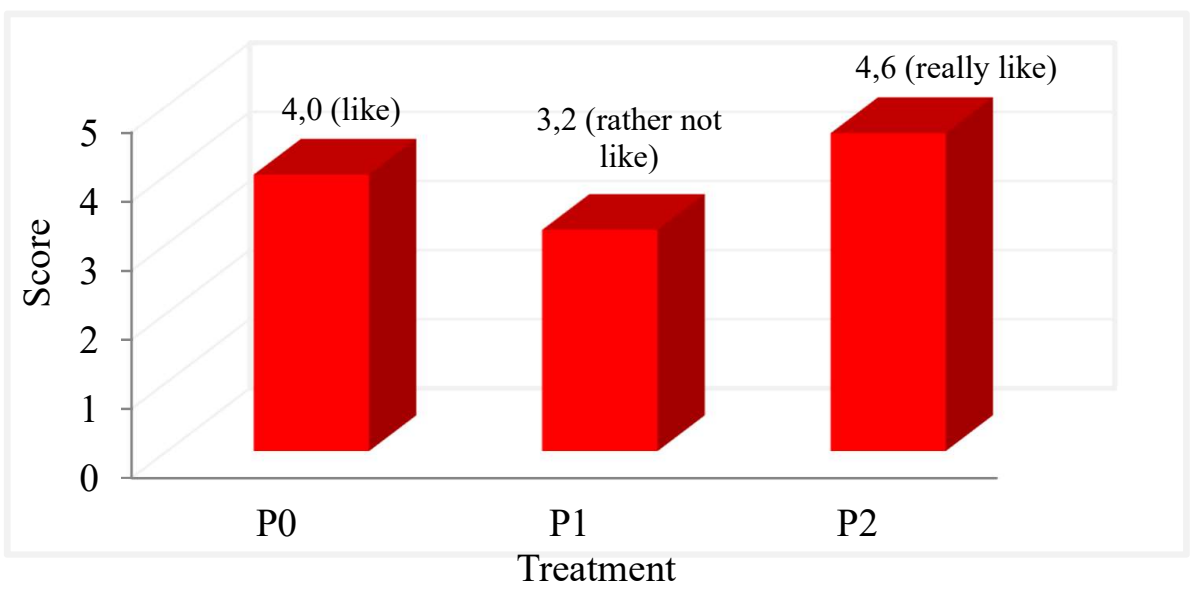

Figure 1. Organoleptic Test Based on Taste

\section{Conclusion and Recommendation}

Organoleptic test results on salted eggs with the addition of herbal plants in the form of bay leaves (Eugenia polyantha) and lemongrass (Cymbopogon citratus DC) for making media gave no significant difference on the organoleptic quality of salted eggs, such as the yolk, albumen, texture , the scent and taste of the salted eggs. However, the addition of bay leaves (Eugenia polyantha) 
and lemongrass (Cymbopogon citratus DC) can be recommended to be used in making of herbal-

flavored broiler salted eggs to maintain and improve the quality of salted eggs.

\section{Acknowledgments}

The author would like to thank the team and the entire extended family of Poultry Production Technology Study Program who participated in this research.

\section{REFERENCES}

[1] A. W. Sukma, "Changes in hedonic quality of roasted salted eggs during storage," Skripsi, Fakultas Peternakan dan Pertanian, Universitas Diponegoro, Semarang, 2012.

[2] E. Rahmawati, "Addition of kitchen lemongrass extract (Cymbopogon Citarus Dc) against physical, chemical and organoleptic properties of salted eggs," Skripsi, Fakultas Teknologi Pertanian Universitas Semarang, Semarang, 2019.

[3] A. Purwati, "The nine superior medicinal plants resulted from the 2004 clinical trial by the POM," [Online]. Available: http://www.beritabumi.or.id. [Accessed: Jan. 2, 2020].

[4] R. G. D. Steel and J. H. Torrie, Statistical Principles and Procedures (translated from: Principles and Procedures of Statistics, translator: B. Sumantri). Jakarta: PT Gramedia,1993.

[5] I. M. Mustika, A.W. Puger, and T. I. Putri, Factors Affecting Egg Production and Quality. Buku Ajar, Fakultas Peternakan Universitas Udayana, Denpasar, 2014.

[6] H. Oktaviani, N. Kariada, and N. R. Utami, "Effect of salting on nutritional content of duck eggs given with shrimp waste," Jurnal Unnes of life Sciense, vol. 1, no. 2, pp. 106-112, 2013.

[7] A. Harianto, “Process of making salted eggs," Jurnal Peternakan, Jakarta. 2016.

[8] H. Sastrohamidjojo, Essential Oil Chemistry. Yogyakarta: Gajah Mada University Press, 2004

[9] A. A. Budiman, Hintono, and Kusrahayu, "The effect of old roasting of salted eggs after boiling on $\mathrm{NaCl}$ Levels, salinity levels and elasticity levels," Animal Agriculture Journal, vol. 1, no. 2, pp. 219-227, 2012.

[10] Nuruzzakiah, H. Rahmatan, and D. Syafrianti, "Effect of salt concentration on protein level and organoleptic quality of duck eggs," Jurnal Ilmiah Mahasiswa Pendidikan Biologi, vol. 1, no. 1, pp. 1-9, 2016.

[11]Jariyah, Susiloningsih, "The effect of soaking chicken meat in betel leaf juice on the storage capacity of chicken jerky," Jurnal Protein, vol. 13, no. 2, pp. 154-160, 2006.

[12] T. Margono, D. Suryati, and S. Hartinah, "Batch study of salt mass transfer in eggs", Laporan Penelitian, Fakultas Teknik Univeristas Sebelas Maret, Surakarta, 2000.

[13] S. Lesmiyati, E. S. Rohaeni, "The Effect of old curing salted eggs on consumer favorability", Prosiding Seminar Nasional Inovasi Teknologi Pertanian Spesifik Lokasi. Balai Pengkajian Teknologi Pertanian, Kalimantan Selatan, 2014.

[14]K. Candrawati, "Decreasing cholesterol levels in salted egg yolks by soaking in powder and extracts of bay leaves (Syzygium Polyanthum) with variations of soaking 
time," Karya Tulis Ilmiah, Fakultas Ilmu Kesehatan, Universitas Setia Budi, Surakarta, 2017.

[15] Rusli and S. Meika, Success in Producing Essential Oils. Jakarta: PT. Agro Media Pustaka, 2010. 